\title{
Water quality deterioration after roof-top storage: implications on their maintenance and management
}

\section{G.S. Wang and H.W. Chen}

Department of Public Health, National Taiwan University, 1 Jen-Ai Road, Sec. 1, Taipei, Chinese Taiwan

(E-mail: gswang@ha.mc.ntu.edu.tw; d93844004@ntu.edu.tw)

\begin{abstract}
This study analyzed 323 water samples from 178 buildings in Taipei, Taichung and Kaoshiung cities to evaluate the water quality deterioration after roof-top storage. Water quality in distribution systems, household intake tanks (point-of-entry) and the tap (point-of-use) were compared. It was observed that chlorine decay is the major factor in deteriorating the water quality after storage. Relatively high water temperature and the presence of higher organic/inorganic impurities are the main reasons that cause the large chlorine decay in Kaoshiung. Most of the microbial regrowth was observed in the samples with chlorine residuals less than $0.2 \mathrm{mg} / \mathrm{L}$, indicating that $0.2 \mathrm{mg} / \mathrm{L}$ of chlorine residual is a suitable criterion to prevent the microbial contamination. After roof-top storage, the chlorine residual, total dissolved solids and turbidity were decreased; however, total bacteria counts and $\mathrm{pH}$ were increased. For better management of household storage systems, some preventive actions has been taken to improve the water quality at point-of-use.

Keywords Chlorine decay; point-of-use; roof-top storage; tap water; total bacteria counts
\end{abstract}

\section{Introduction}

Household storage tanks are essential facilities for drinking water supply in South-East Asia. These storage tanks are installed to provide sufficient hydraulic pressure and to balance the water usage throughout the day. In Taiwan, most of the buildings have two storage facilities for drinking water: the intake tank and the roof-top storage tank. In general, a small intake tank is located on the ground or underground level of the building and serves as the point-of-entry for drinking water from the distribution system. The intake water is then pumped from the intake tank to the roof-top storage tank, where the water is flow by gravity to the tap (point-of-use). In order to prevent a water supply shortage, the roof-top storage tanks are built much larger than necessary in most of the cases. The chlorine residual decreases rapidly in the storage tanks due to the long retention time in those over-sized tanks or due to the improper design and/or maintenance of the tanks. Under these situations, the drinking water quality will deteriorate after storage.

A survey in Taiwan provided some reasons for the decay of the chlorine and pathogen intrusions in household water supply systems (Lo, 1991):

1. Improper storage tank design, including improper tank size, access manhole, ventilation hole, overflow pipes, etc.

2. Groundwater infiltration through the cracks of underground intake tanks.

3. Operational defects such as the cross-connection or back-siphon of the contaminants.

4. Lack of regular maintenance and management such as routine sanitary inspection and cleaning.

The objective of this study was to compare the water quality changes after household storage based on the water samples collected from 178 buildings. Chlorine residuals, total bacteria counts, coliform groups and other related water quality parameters between intake tank and point-of-use in each selected building were compared. 


\section{Methods}

For this study, 178 buildings located in three metropolitans (Taipei, Taichung and Kaoshiung) in Taiwan were selected. The households were selected based on their building type, such as public accessible buildings (hospitals, schools and department stores) and private buildings (houses, apartment complex and commercial buildings). For each selected building, water samples were collected from the building's water intake tank and a tap in the ground floor between May and September 2001. The selected tap water sample has flowed through the intake tank, roof-top storage and the inside pipeline of the buildings. The parameters measured included: $\mathrm{pH}$, temperature, chlorine residual, turbidity, conductivity, total bacteria counts, total coliform groups and ammonia nitrogen (Standard Methods for the Examinations of Water and Wastewater, 1989). On all of the building visits, a standard sheet was used to conduct a sanitary inspection for the household storage facilities and to record the building types, storage tank material and sizes, tank cover suitably sealed, and a visual sanitary inspection about the storage tank status. For comparison, distribution system water quality data reported by Taiwan's EPA were used to represent the water quality without intake or roof-top storages. Table 1 summarizes the general water quality parameters in the distribution systems of the sampling area.

\section{Results and discussion}

\section{Results on water quality analysis}

In total 178 buildings were included in this study, 323 samples were collected for water quality analysis (145 intake waters and 178 tap waters). All of the buildings selected used conventionally treated water from the distribution systems. Table 2 gives the statistics of the water quality analysis.

In water treatment processes, disinfection is the most important barrier to inactive and to prevent the microbial contamination in distribution system. Chlorine is a widely used disinfectant due to its ability to serve as both the primary and secondary disinfectant. In Taiwan, the Drinking Water Quality Standards specifies that $0.2-1.0 \mathrm{mg} / \mathrm{L}$ free residual chlorine is required in the distribution system. By this reason, chlorine is used as the major disinfectant in all of the water treatment plants in Taiwan. In sub-tropical areas like Taiwan, chlorine residual in distribution system is one of the most important variables for protection of public health, and special attention should be paid to monitor its decay and factors related to its decay in the distribution system. As residual chlorine decreases, the overall quality of the water deteriorates as a result of increasing microbial activities.

\section{Turbidity change after household storage}

The results of the turbidities in the distribution systems, household intake tanks and tap water after roof-top storage are given in Figure 1. Since the result obtained in Taichung

Table 1. Distribution systems water quality in the study areas. Note: Values are average data obtained in May-September, 2001

\begin{tabular}{|c|c|c|c|}
\hline Sampling area & Taipei & Taichung & Kaoshiung \\
\hline Average water temperature $\left({ }^{\circ} \mathrm{C}\right)$ & $21 \pm 1$ & $21 \pm 1$ & $25 \pm 2$ \\
\hline $\mathrm{DOC}(\mathrm{mg} / \mathrm{L})$ & $0.73( \pm 0.25)$ & $0.71( \pm 0.21)$ & $1.45( \pm 0.60)$ \\
\hline Turbidity (NTU) & $0.33( \pm 0.30)$ & $0.70( \pm 1.08)$ & $0.26( \pm 0.45)$ \\
\hline $\mathrm{pH}$ & $7.08( \pm 0.17)$ & $7.02( \pm 0.14)$ & $7.32( \pm 0.22)$ \\
\hline Chloride (mg/L) & $0.53( \pm 0.11)$ & $0.73( \pm 0.12)$ & $0.60( \pm 0.19)$ \\
\hline Ammonia nitrogen (mg/L) & $0.05( \pm 0.02)$ & - & $0.04( \pm 0.03)$ \\
\hline Hardness $\left(\mathrm{mg} / \mathrm{L}\right.$ as $\left.\mathrm{CaCO}_{3}\right)$ & $36( \pm 11)$ & $136( \pm 18)$ & $218( \pm 46)$ \\
\hline THMs (mg/L) & $0.009( \pm 0.008)$ & $0.020( \pm 0.01)$ & $0.035( \pm 0.019)$ \\
\hline
\end{tabular}


Table 2 Results of the water quality analysis

\begin{tabular}{|c|c|c|c|c|c|c|}
\hline \multirow[t]{2}{*}{ Sampling points } & \multicolumn{2}{|c|}{ Taipei } & \multicolumn{2}{|c|}{ Taichung } & \multicolumn{2}{|c|}{ Kaoshiung } \\
\hline & Intake & Tap & Intake & Tap & Intake & Tap \\
\hline Total sample number & 75 & 87 & 15 & 35 & 55 & 56 \\
\hline \multicolumn{7}{|c|}{ \#failed to meet the water quality standards } \\
\hline Chlorine residual & 3 & 11 & 1 & 11 & 21 & 43 \\
\hline Turbidity & 0 & 1 & 0 & 0 & 2 & 0 \\
\hline $\mathrm{pH}$ & 0 & 0 & 0 & 0 & 0 & 0 \\
\hline Ammonia nitrogen & 0 & 0 & 0 & 0 & 0 & 0 \\
\hline TDS & 0 & 0 & 0 & 0 & 8 & 10 \\
\hline Total coliform & 1 & 3 & 0 & 3 & 0 & 4 \\
\hline Total bacteria count & 4 & 8 & 1 & 3 & 12 & 24 \\
\hline
\end{tabular}

was similar to those obtained in Taipei, only data in Taipei and Kaoshiung were shown. In Taipei, the mean turbidity in the distribution system was $0.28 \mathrm{NTU}$, increased to $0.46 \mathrm{NTU}$ in the household intake tank, and then decreased to $0.44 \mathrm{NTU}$ in tap water. For Kaoshiung, the mean turbidity in the distribution system was $0.22 \mathrm{NTU}$, increased to 0.94 NTU in the household intake tanks, and then reduced to 0.57 NTU in tap water. The increase of the turbidity in the household intake tanks should result from the rapid mixing effects in the small intake tanks, and some settled particles on the bottom of the intake tanks were re-suspended after the mixing. However, the settling effect due to the long residence time in the large roof-top storage tank resulted in the reduction of the turbidity in the tap water.

\section{Chlorine residuals and total bacteria counts after roof-top storage}

Figure 2 gives the residual chlorine in samples collected from the distribution system, household intake tanks and tap water after roof-top storage. The corresponding data distribution of total bacteria counts were also given in Figure 2. In Taipei (located in northern Taiwan), mean free chlorine was $0.5 \mathrm{mg} / \mathrm{L}$ in distribution system, $0.4 \mathrm{mg} / \mathrm{L}$ in intakes, and $0.3 \mathrm{mg} / \mathrm{L}$ in tap water. In Kaoshiung (located in southern Taiwan), mean free chlorine decreased from $0.7 \mathrm{mg} / \mathrm{L}$ in the distribution system to $0.3 \mathrm{mg} / \mathrm{L}$ in intake, tank with

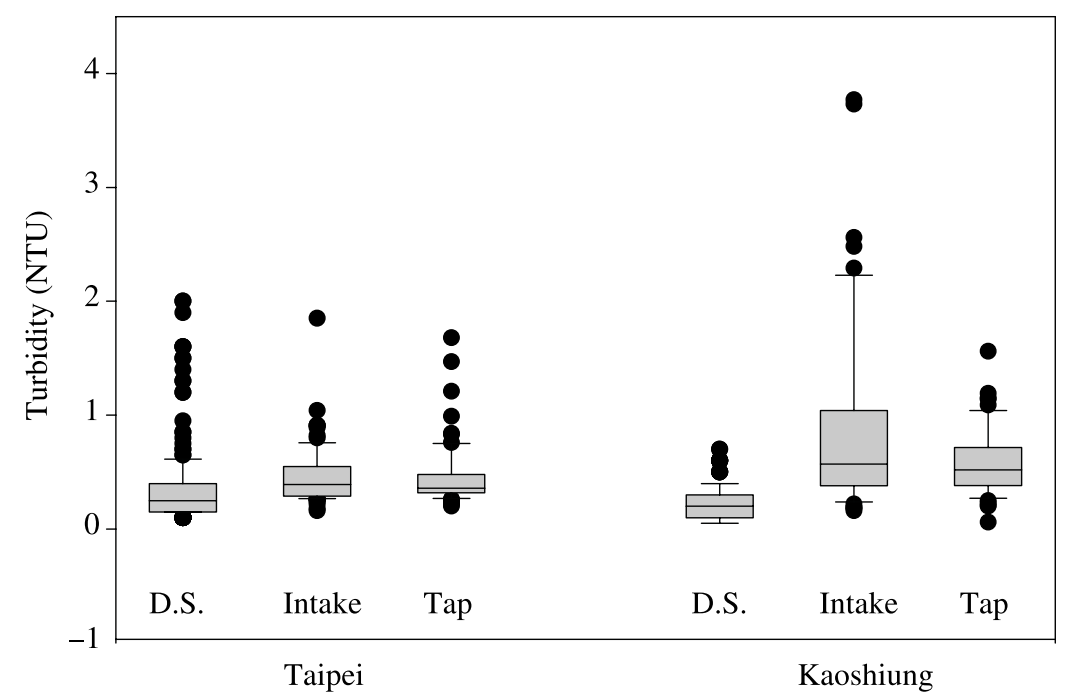

Figure 1 Changes of the turbidity in distribution systems (D.S.), intake water and tap water in Taipei and 

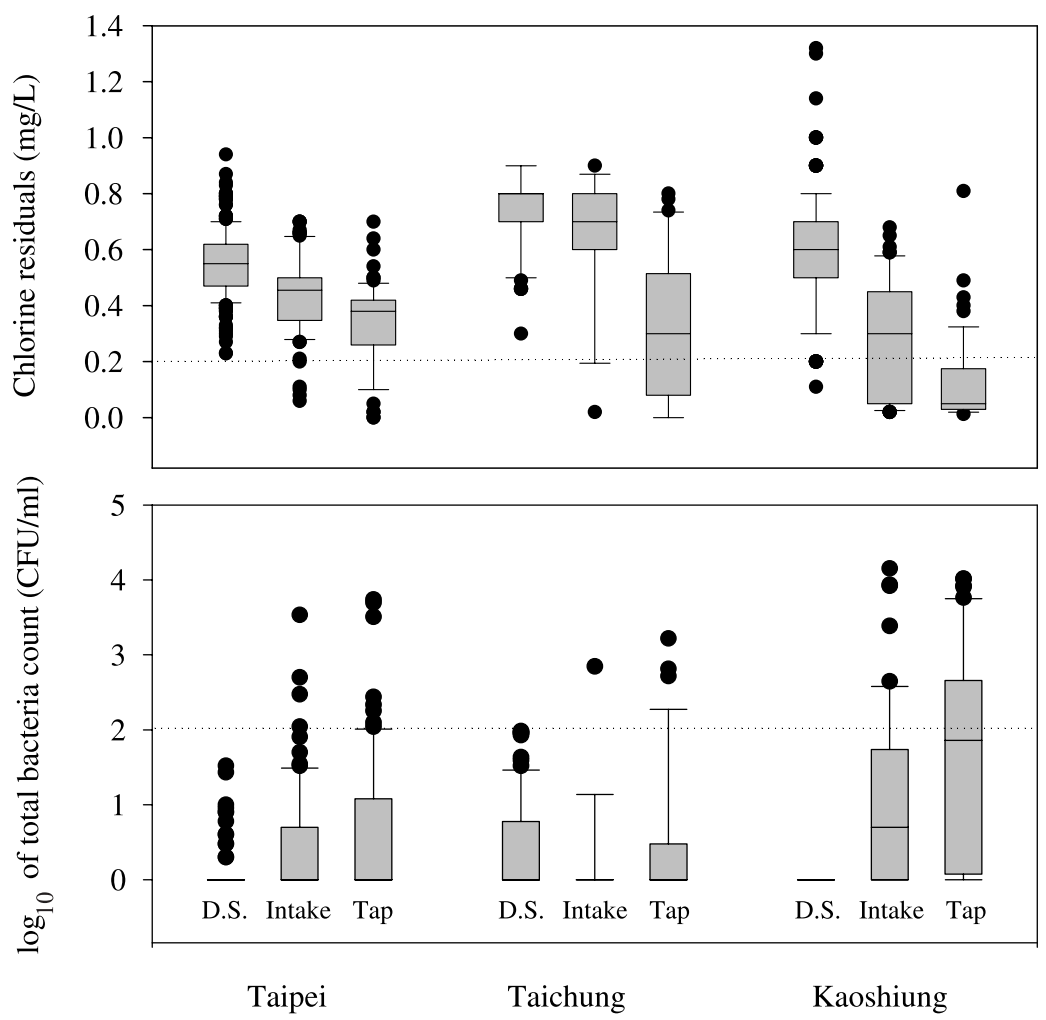

Figure 2 Comparisons of chlorine residuals (top) and total bacteria counts (bottom) in study areas for distribution systems (D.S.) intake water; and tap water after roof-top storage. Dotted lines indicate the current standards

further decreases to $<0.1 \mathrm{mg} / \mathrm{L}$ in tap water. In general, the regulated minimum chlorine residual in the closed distribution systems can be fulfilled, and no significant chlorine decay was observed. However, a wide variation in chlorine residual in distribution system was observed in Kaoshiung. This result indicates that the chlorine decreases more rapidly in finished water with elevated average water temperature and higher organic/inorganic impurities (see Table 1). Figure 2 also shows a minor decrease in chlorine concentration in the intake tank, and most of the chlorine residual was lost after roof-top storage. The large chlorine loss after roof-top storage may be due to the reaction between the chlorine and the walls of the storage tank, the long retention time in roof-top storage, the material of the storage tank, the presence of biofilm and organic layer on the storage tank walls (AWWARF, 2001; USEPA, 2001). Based on the total water samples analyzed, about $35 \%$ of them do not meet the current drinking water standards in Taiwan; and most of these were collected from taps. The major parameters that do not meet the water quality standards are chlorine residual, total bacteria counts, and total coliform groups. Most of those disqualified samples were taken from the taps after roof-top storage, especially in Kaoshiung City (Table 2). Among the water quality parameters analyzed in this study, it is observed that chlorine residual, total dissolved solids (TDS) and turbidity also decreased after storage. However, total bacteria counts and $\mathrm{pH}$ increased after storage.

The decreased chlorine concentrations resulted in the growth of the microbial activities in the household water. As shown in Figure 2, the total bacteria counts increased rapidly after roof-top storage. Since the re-growth of microbials in the distribution system and intake tanks were not as apparent as those that appeared after roof-top storage, the 
main entry routes for potential pathogens should be in roof-top storage tanks. There are some pathways for pathogens into the household drinking water system, for example, the uncovered or improperly covered storage tanks (both intake and roof-top). Although covered storage tanks are a much better barrier than the uncovered ones, they can still be susceptible to airborne microorganisms entering through access hatches, overflow pipes and vents, roofs, and poorly constructed sidewall joints (AWWARF, 2001). Among the buildings selected in this study, coliforms were detected in $9 \%$ of the total tap samples. A clear inspection of the roof-top storage tanks indicated that most of the tap samples with coliforms have defects on the roof-top tanks. In some cases, the pathogens may also penetrate into the underground intake tanks via the improperly covered access hatches or via groundwater infiltration.

\section{Correlations between chlorine residuals and total bacteria counts}

In addition to these infrastructure and operational failures, whether the chlorine residual is enough to prevent the microbial growth or not is of great concern. Although $0.2 \mathrm{mg} / \mathrm{L}$ of the free chlorine residual is required throughout the distribution system, little information is available to demonstrate the ability of this chlorine residual to prevent the microbial intrusion at all points of the water consumption (Propato and Uber, 2004). Figure 3 shows the correlation between the total bacteria counts and the chlorine residuals in the distribution system, intake tanks and the taps after roof-top storage. Although the water samples were taken from three cities with different water quality, the total bacteria counts increase with the decrease chlorine residual for all of the samples. As mentioned earlier, larger variations in both chlorine residual and bacteria counts were observed in the intake and tap samples taken in Kaoshiung. However, data in Figure 3 also showed that $0.1 \mathrm{mg} / \mathrm{L}$ of the free chlorine residual could be the threshold values for bacteria control - most of the samples which failed to meet the $100 \mathrm{CFU} / \mathrm{mL}$ standard fell in this range. This phenomenon is more apparent at tap water samples which have passed through roof-top storage. The data in Figure 3 also demonstrated that the current $0.2 \mathrm{mg} / \mathrm{L}$ free chlorine residual is suitable for prevention of bacterial re-growth in distribution systems. Wright et al. (2004) reviews 57 related studies that measured bacteria counts for household source and stored water, and reported that microbial contamination of water between source and point-of-use is widespread, especially in urban areas with uncontaminated supplies. Trevett et al. (2004) examined water quality in 43 Honduran households, and also reported that the water quality deteriorated regularly and frequently after collection. However, a regular maintenance on the water supply system can reduce the risks of the household water quality deterioration. Detailed data analysis on samples collected in Taipei City showed that buildings with regular maintenance have higher chlorine residual $(0.39 \mathrm{mg} / \mathrm{L})$ in tap water; as a comparison, the tap water's average chlorine residual of buildings without regular maintenance was $0.31 \mathrm{mg} / \mathrm{L}$.

\section{Maintenance and management issues}

Due to the relatively high percentages on the violation of the Water Quality Standards in water samples taken after household roof-top storage, Taiwan's EPA has initiated an "Intake and Roof-top Storage Tanks Self Inspection Program". In this three year program (2004-2006), all of the schools, hospitals, department stores and large commercial buildings and apartment complexes are required to conduct a simple self inspection on their intake tanks and roof-top storage tanks. A training course was offered by local environmental authorities to provide the necessary information about the sanitary inspections for the household drinking water facilities with special focus on the intake and roof-top storage tanks. In addition, Taiwan's EPA also provides Chlorine Residual Test Kits to those 
Taipei

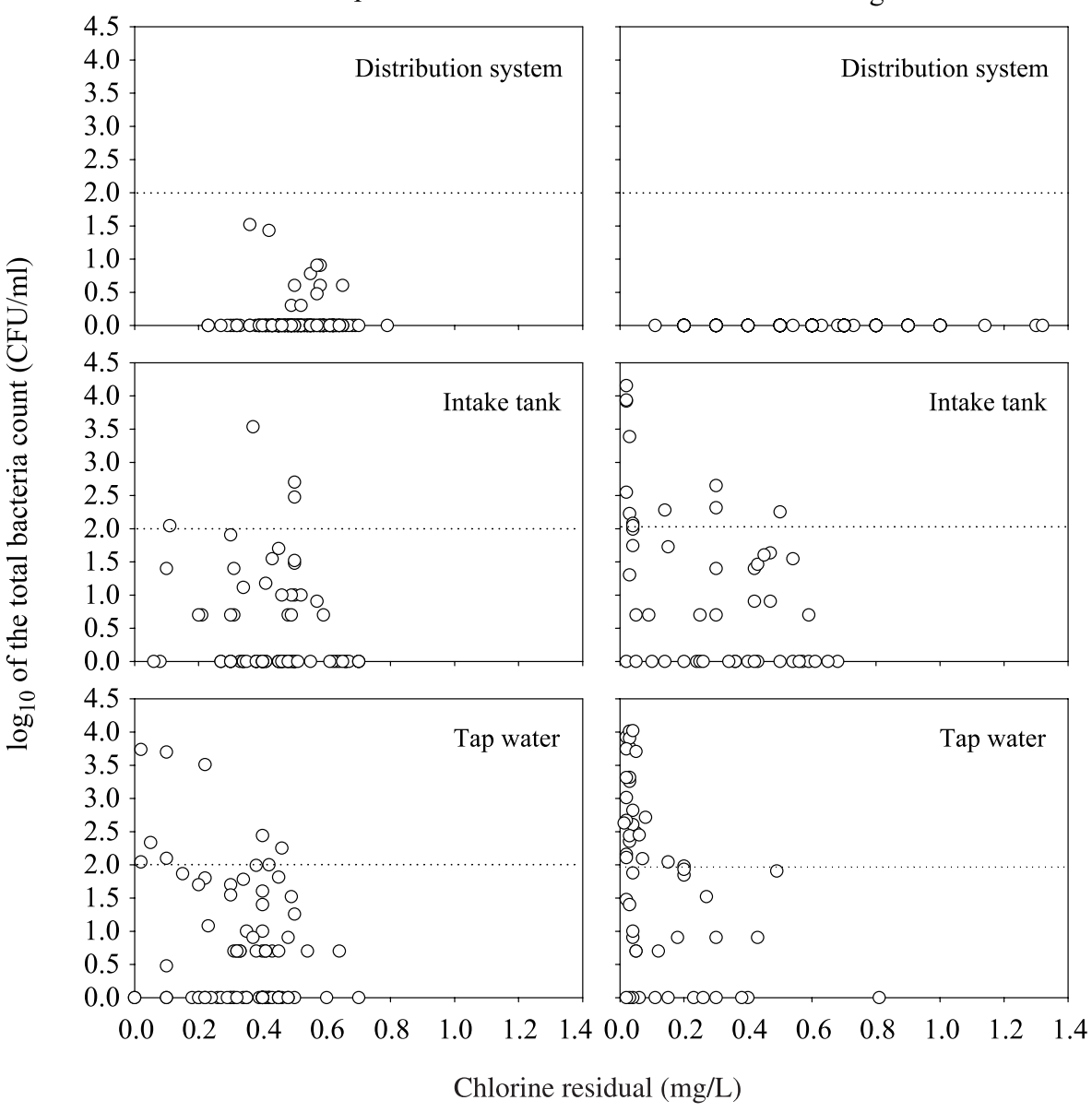

Figure 3 Correlation between chlorine residuals and total bacteria counts in Taipei and Kaoshiung for distribution systems (top), intake tanks (middle) and tap water (bottom) after roof-top storage. Horizontal dotted lines denote the current standard on total bacteria counts

responsible for these buildings and asks them to measure the free chlorine in the tap water. They are also required to report the results of the sanitary inspection and the residual chlorine to the EPA via Internet. For the general public, the EPA and water utilities provide consulting assistances on cleaning and maintenance of household water storage facilities. To ensure the success of this self-inspection program, the local environmental protection authorities will provide necessary assistance upon requests. After this program, Taiwan's EPA will be able to collect enough information and establish enforceable regulations to prevent water quality deterioration due to the presence of roof-top storage tanks.

\section{Conclusions}

The presence of roof-top storage tanks may cause a great impact on the drinking water quality at point-of use. Based on the results of this study, the chlorine residual decreases after household roof-top storage; and result in an increase of microbial activities. It was also observed that deficiencies on the storage tanks may result in severe coliform contamination. The correlation between the total bacteria counts and the chlorine residuals indicated that the current $0.2-1.0 \mathrm{mg} / \mathrm{L}$ free residual chlorine standard in the distribution 
system is suitable for prevention of microbial re-growth. However, no major water quality problems were observed on the buildings with regular maintenance of household water supply systems; this observation demonstrates that suitable maintenance and regular cleaning of the household water storage facilities is essential to prevent potential water quality deterioration from roof-top storage tanks. In order to reduce the health risks posed by the household roof-top storage tanks, a routine sanitary inspection and cleaning of the storage tank is recommended.

\section{Acknowledgements}

This study was support by EPA, Taiwan under grant number EPA-90-G108-03-101. The authors thank the staff of the Taiwan Water Supply Corporation and Taipei Water Department for their assistance during the period of this study.

\section{References}

AWWARF (2001). Pathogen Intrusion Into the Distribution System, AWWARF, Denver, CO.

Lo, M.C. (1991). Study on Water Safety Improvements in Building's Water Intake Tanks and Roof-top Storage Tanks, Architecture and Building Research Institute, Ministry of Interior, Taiwan.

Propato, M. and Uber, J.G. (2004). Vulnerability of water distribution systems to pathogen intrusion: how effective is a disinfectant residual? Environ. Sci. Technol., 38(1), 3713-3722.

Standard Methods for the Examination of Water and Wastewater (1989). 17th edn, American Public Health Association, Washington, D.C., USA.

Trevett, A.F., Carter, R.C. and Tyrrel, S.F. (2004). Water quality deterioration: a study of household drinking water quality in rural Honduras. Int. J. Environ. Heal. R., 14(4), 273-283.

USEPA (2001). Controlling Disinfection By-Products and Microbial Contaminants in Drinking Water, EPA/600/R-01/110. United States Environmentel Protection Agency, Washington DC, USA.

Wright, J., Gundry, S. and Conroy, R. (2004). Household drinking water in developing countries: a systematic review of microbiological contamination between source and point-of-use. Trop. Med. Int. Hlth., 9(1), 106-117. 